STUDIA ROSSICA POSNANIENSIA, vol. XL, cz.1: 2015, pp. 217-224. ISBN 978-83-232-2878-3. ISSN 0081-6884. Adam Mickiewicz University Press, Poznań

\title{
СЕМАНТИКА ПРОТИВИТЕЛЬНОСТИ В СИНХРОНИИ И ДИАХРОНИИ
}

\author{
SEMANTICS OF ADVERSATIVITY IN SYNCHRONY AND DIACHRONY
}

\author{
МАРИЯ МИЛОВАНОВА
}

\begin{abstract}
The author of this article presents the semantics of adversativity as subjective contraposition (vs. spatial, logical and grammatical contraposition). The article discusses the history of the transformation of spatial meaning into adversative meaning. Basic examples include words that belong to the same etymological family, such as nротиb, напротив, противныи, прочь, прямо и просто (which are equivalents of the Polish words: przeciw, naprzeciw, przeciwko, przeciwnie, przecie(z), oprócz, etc.).
\end{abstract}

Мария Милованова, Государственный институт русского языка им. А.С. Пушкина, Москва - Россия.

Факты противительности, символизирующей отрицательную оценку, можно рассматривать как отражение актуальных мыслей современного человека (С.Д. Кацнельсон), свидетельствующих о его актуальном интересе (Л.В. Щерба).

В основе понятия противительность лежит явление противопоставления, неоднородное по сути. Говоря о противопоставлении, имеем в виду следующие его понятийные формы: пространственное (объективное), логическое (объективно-логическое), грамматическое (логико-грамматическое, или объективно-субъективное) и, наконец, субъективное противопоставление, т. е. собственно противительность. Противопоставление - это вещественная, материальная составляющая слова с противительным значением, тем не менее для возникновения противительности в языке существование отношений противопоставления - условие необходимое, но недостаточное: модальность, экспрессивность и оценочность составляют субъективную сущность противительности. В семантической структуре противительного слова значение противопоставления дополнено обязательным субъективно-экспрессивным, субъективно-оценочным компонентом.

Противительность можно охарактеризовать как субъективное противопоставление (противопоставление Я - не-Я), осложненное смысловыми субъективно-оценочными компонентами возражения, несогла- 
сия, отрицания, ограничения, враждебности, протеста, возмущения, негодования и т. Д. Противительность - синкретичная семантика, объединяющая семы противопоставления, отрицания, уступки и ограничения как семантической доминанты в этом смысловом единстве. Каждое противительное слово содержит эти семантические компоненты, но в разных пропорциях.

Маркерами этой семантики и носителями идеи противительности в современном русском языке становятся слова проти , напротия, с разной степенью частотности встречающиеся в современной речи, и противительный союз но: - Я против, ты слышишь меня? Я не была В Греции! Никуда они не поедут (Л. Улицкая, Пиковая дама); Так что же - возмутитесь вы - значит, тайна не может быть правдой? Напротив, она-то именно и есть правда... (А. Пятигорский, Вспомнишь странного человека); Одной ююбви музыка уступает. / Но и ююбовь - мелодия (А.С. Пушкин, Моиарт и Сальери).

В диахронии создание средств противительной семантики происходило на основе средств, выражающих пространственные отношения - и на синхронном уровне противительная семантика демонстрирует сохранившуюся живую и непосредственную связь с пространственным значением. Связь двух значений - первичного и производного - рассмотрим на примере слов против и напротив, противный, просто и прямо, прочь.

Слова против и напротиъ интересны тем, что они в своей современной синкретичной пространственно-противительной семантике фиксируют результат длительного, многовекового процесса развития противительного значения, но сохраняют при этом исходное пространственное значение. Важен и другой факт: в настоящий момент эти слова делят сферы влияния - слово протиъ выражает противительное значение, пространственное же значение можно считать уходящим или даже ушедшим. За наречием-предлогом напротив закрепляется значение пространственное, в роли вводно-модального слова, частицы и модального союза напротив обладает противительным значением.

Формирование субъективной противительной семантики отражает, например, ближайшая история слова противныи. В словаре В.И. Даля дается значение локальное - значение пространственного противопоставления: 'находящийся против / напротив, расположенные друг против друга': Наш дом белый, а противный розовыи; Две противные сосны (ср. также: противный ветер - 'встречный, навстречу')1. В результате метафорического переноса развиваются значения противоположности 'иной, другой, противоположный, обратный' и противоречия 'несовместимый с чем-л., противоречащий чему-л.'. Эти значения сохра-

1 В.И. Д а ль, Толковый словарь живого великорусского языка, т. 3, Москва 1994, с. 520. 
няются в устойчивых оборотах: доказательство от противного (ср. разг.: попробуй доказать противное), в противном случае, противное природе. Основным значением слова противный в современном русском языке становится значение, переводящее его в разряд субъективно-оценочных слов, это значение 'неприятный'2. Субъективный компонент семантики прилагательного, унаследованный от семантики слова против (против $/$ напротив $\rightarrow$ противник = враг), получает дальнейшее развитие в сторону усиления негативной коннотации, ср. современные производные: противненький, противнущий (разг.-просторечн.), противно, опротиветь, противозина (просторечн.) и др.

Логика развития семантики слов просто и прямо и их новейшая история свидетельствуют о связи пространственного и противительного значений - и на наших глазах происходит втягивание слов прямо и просто в сферу противительности. Скрытая сема ограничения, которая содержится в лексическом значении прилагательных простой и прямой и производных наречий, способствует переходу слов в разряд ограничительных частиц, а у слова просто - в разряд противительных союзов, аналогов союза но.

Два корня - -прост- и -прям- - на протяжении долгого времени их параллельного существования делят семантическое пространство как в обозначении первичного смысла 'впереди', так и в обозначении некоторых производных смыслов. В древнерусском и старославянском языках прилагательное простъ (простыи) первоначально имело значение 'прямой'3, которое является основным значением современного польского слова с этим корнем: linia prosta, proste włosy. В толковании В.И. Даля прямо - 'просто, по прямой черте, не криво'4. По-видимому, корень -npocm- / -prost- старше и имел значение, перешедшее впоследствии в русском языке к словам с корнем -прям-. Слова просто и прямо имеют области пересечения в современном разговорном языке: Прямо / просто загляденъе!; Не знаю просто / прямо, что делать!; Так он тебе прям(о) / просто и отдаст книгу!

Слово прямь (прьмъ), бывшее в древнерусском языке и имевшее пространственное значение, сохранилось в говорах: прямъ (чего) - 'прямо

2 Контаминация двух значений (архаичного и актуального) лежит в основе многочисленных шуток и каламбуров: в совсем противном случае; А что касается зарубежных премий, то пора уже привыкнуть, что в последнее время нашим кинематографистам их дают от противного. Чем противнее, тем больше шансов получить („Литературная газета” 2006, № 48); Жена быстро забеременела, как шутили в батальоне - „так быстро, что даже противно природе” (М. Шишкин, Записки Ларионова).

${ }^{3}$ И.И. С р е $з$ н е в с к и й, Словарь древнерусского языка, т. 2, Москва 1989, с. 1578, 1582; П.Я. Ч е р н ы х, Историко-этимологический словарь современного русского языка, т. 2, Москва 2006, с. 72.

4 В.И. Д а л ь, указ. соч., с. 531. 
насупротив (чего)', прямо (чего) - 'против, насупротив'; ср. также: просто (чего) - 'прямо насупротив, напротив, супротив'5. Понятия „прямо” и „напротив" оказались связанными, поскольку собственно прямая - это и есть линия взгляда, то, что напротив, перед глазами. И польское слово wprost соединяет значения 'прямо' (в переносном значении - 'откровенно') и 'впереди, напротив', причем во втором значении имеет синоним - naprzeciwko, слово, генетически и семантически родственное русским протиъ и напротиъ. Сема, объединяющая пространственные значения двух корней - прост-/ -prost- и -nрям-, - это сема 'линия, не допускающая отклонений, ответвлений, без изгибов или уклонов': „Прямая (линия) определяется в геометрии как 'кратчайшее расстояние между двумя точками'. Но в литературном языке это, очевидно, не так. Я думаю, что прямой мы называем в быту 'линию, которая не уклоняется ни вправо, ни влево (а также ни вверх, ни вниз)'"6. Ср. употребление слов прямой и прямо (= не криво, не косо) в контексте ситуативного противопоставления: Один идет прямым путем, / Другой идет по кругу / И ждет возврата В отчий дом, / Ждет прежнюю подругу. / А я иду - за мной беда, / Не прямо и не косо, / А В никуда и $b$ никогда, / Как поезда с откоса (А. Ахматова). Ср. также: в известных строчках Б. Пастернака Любить иных - тяжелый крест, / А ты прекрасна без извилин... поэтическая характеристика прекрасна без извилин соответствует по существу формуле просто / прямо красавииа.

'Недопущение, отсутствие каких-либо отклонений' - это и есть скрытая сема ограничения в исходном пространственном значении слов прямой и простой, которая становится предпосылкой в развитии противительной семантики, предполагающей ограничение, и переход наречия в частицу со значением, окрашенным оттенком модального, волевого ограничения.

Благодаря включению частицы прямо в контекст эмоциональноэкспрессивной речи в ее ограничительной семантике исчезает сема уточнения, зато актуализируется скрытая модальность и коннотативность: слово становится способно выражать максимальную степень несогласия, протеста, что роднит его с выражающей экспрессивное несогласие частицей boт ещё! - с одной стороны, с другой - с такими экспрессивно насыщенными, но эмоционально сдержанными словами, как не (не буду) и против (я против). Ср.: Прям(о) так я и буду делать домашнее задание!

${ }^{5}$ И.И. С р е $з$ н е в с к и й, указ. соч., т. 2, с. 1671; В.И. Д а л ь, указ. соч., т. 3, c. $531-532,513$.

6 Л.В. Щ е р б а, Языковая система и речевая деятельность, Ленинград 1974, с. 280.

7 О модальной частице прямо при выражении возражения или отрицания см.: А.Ф. П р и я т к и н а, Е.А. С т а р о д у м в в а, Г.Н. С е р г е е в а и др., Crobарьслужебных слов русского языка, Владивосток 2001. 
Ограничительная сема в структуре лексического значения слова просто развивается сначала в рамках лексико-грамматического значения частицы, а затем преобразовывается в значение противительного союза. Организуя противопоставление (отрицание неистинного - утверждение истинного) и занимая место союза во второй части противопоставления, слово просто по семантике сближается с противительным союзом но, имеющим значение ограничения: - Ты о чем, мама? Со мной ничего... Просто $(=$ но) я раздумал. Просто $(=$ но) я никогда не буду боксером (В. Драгунский, Денискины рассказы).

Новейшая история слова-конструкции Прочь! в его художественном, отвлеченно-образном употреблении находится вне связи с понятием места и указанием направления - исходным и основным современным значением слова: Пойди прочь, безумный мальчищка! Где тебе ездить на моем коне? (М.Ю. Лермонтов, Герой нашего времени). Буквально на наших глазах происходит изменение в семантике слова прочь и движение в сторону системы противительных слов - прочь в значении отказа от чего-либо, нежелания видеть / слышать кого / что-либо: Вопли прессы, / Мессы, конгрессы, / Жены - как ночъ... / Прочь! (Саша Черный); Здесь, В Блумбери, я остаюсь для повторения урока прошлого лондонского лета, хэммстедского лета, хэмпширского лета... Прочь! (А. Пятигорский, Вспомнишь странного человека).

Древнерусский язык еще хранил, польский сохраняет значение 'кроме' слова прочь, унаследованное из праславянского периода развития слова: др.-рус. прочь, проче, опричь; польск. prócz, oprócz8; Opriczniki Iwana Groźnego, 'oddzieleni, osobni od państwa' - 'отделенные, отдельные, особые' (т. е. 'все, кроме'); 'krom, okrom', в 17 в. 'tylko' - 'только'9. Ср.: Пригоженький, когда настанет время / Снегурочке ююбить, уж никого-то / Опричь тебя не полюблю (А.Н. Островский, Снегурочка); Znowu nic nie stychać oprócz trzęsienia i turkotu... (B. Prus, Anielka).

Нельзя оставить без внимания и мнение П.Я. Черных о первичности значений слова прочъ: „Спорным следует считать вопрос о старшем значении прочь < др.-рус. проче... Возможно, значение 'вне', 'кроме' - старше"10.

Современному абстрактному значению слова кроме ('за исключением') в русском языке предшествовало вполне конкретное, вещественное значение: 'надрез' > 'край'. То же можно предположить и в отношении слова прочъ: значение 'кроме, за исключением, исключая' могло

8 А. П р е о б р а ж е н с к и й, Этимологический словарь русского языка, Москва, 1910-1914, с. 654; И.И. С р е з н е в с к и й, указ. соч., т. 2, с. 693; М. Ф а с м е р, Этимологический словарь русского языка, т. 3, Москва 2006, с. 386.

${ }^{9}$ A. B r ü c k n e r, Stownik etymologiczny języka polskiego, Warszawa 1957, c. 437.

10 П.Я. Ч е р н ы х, указ. соч., т. 2, с. 76-77. 
появиться только в результате изменения значения, имевшего вполне объективный, материальный характер.

В современном русском языке значения слов кроме и прочь пересекаются: Кроме шуток! = Шутки прочь! Точка соприкосновения, основа для сближения значений двух слов - наличие воображаемой черты, линии, границы. Возможно, что праславянское слово *prokь и могло обозначать какую-то действительно существующую или представляемую линию, по-другому - край. Ср. современное толкование одного из значений слова край - например: „Край. Предельная линия, ограничивающая поверхность плоского предмета, грань"11.

Таким образом, основой для формирования противительности становятся две неразрывно связанные разновидности пространственного значения - это значение противопоставления (включая значение указания направления на объект) и значение точки, черты, линии, т. е. материальной границы, делящей пространство на две части.

Метафорически переосмысленные, эти два значения в истории языка были трансформированы в семантику модального ограничения и модального противопоставления - составные части единой противительной семантики. Однако противительность как смысл обязана своим происхождением не просто пространственному значению, но такому выражению пространственного значения, которое сопровождалось бы элементом волевого присутствия человека (субъекта). Этот „зародыш волюнтаризма” (С.Д. Кацнельсон) в синкретичной семантике праслова стал исходной точкой в развитии противительности. Когда мы говорим о противительности как развитой и сформировавшейся семантике, то речь всегда идет о двух взаимосвязанных элементах - противопоставлении (субъекта объекту, в т. ч. и другому субъекту в качестве объекта) и границе противопоставления, определяемой волей субъекта: по существу - это перенос границы противопоставления.

Семантическая трансформация пространственного значения в противительное в диахронии - это в первую очередь история слов, восходящих к одному этимологическому гнезду или макрогнезду с вершиной - индоевропейским корнем *pr-, включавшим расширители, или детерминативы ${ }^{12}$, и составляющим основу современной противитель-

11 Толковыи словарь русского языка в 4-х томах, под ред. Д.Н. Ушакова, т. I, Москва 1935-1940, стлб. 1495.

12 О структуре индоевропейского корня см.: Э. Б е н в е н и с т, Индоевропейское именное словообразование, Москва 1955; Э.А. М а к а е в Структура слова в индоевропейских и германских языках, Москва 1970; С. П а в и д и с, Теория индоевропейского корня и формирование этимологического макрогнезда при помощи моделирования фономорфологических вариантов корня в германских языках, [в:] Научные труды. Лингвистика, Riga 2004. 
ности: против / напротив, супротив / насупротив; прочь, впрочем; (на)поперек, вопреки и др. Ср. в польском: przeciw / naprzeciw, przeciwko, przeciwnie, przecie(ż): - Co to za śmieszny spisek knujecie przeciwko mnie? (B. Prus, Lalka); ср. пространственное значение польского слова naprzeciw: Podnióst się z ławki i szedt naprzeciw nich jak lunatyk (там же).

Следует заметить, что в индоевропейском, впоследствии в праславянском и в древнерусском языках имелось несколько корней - носителей значения, восходящего к пространственному и способного к развитию противительности, однако их семантическое развитие пошло по другому пути и были реализованы другие семантические потенции. Например, корень *-pak- / -naк-: служебные слова паки, пакы, пако, пакъ указывают на семантику противительности; значением слова пакость в древнерусском языке было 'препятствие', 'прекословие', 'вред'13. Ср. в диалектах: наопак(o) - 'наоборот, навыворот, напротив, напротивку': Один глядит сюда, другой наопако (пространственное значение); Такой задор, всякому наопак отвечает! (противительное значение) ${ }^{14}$. Ср. польское na opak - 'наоборот, шиворот-навыворот'.

В конечном итоге история противительности - это история противопоставления субъекта объекту и проявления воли субъекта по отношению к объекту. По афористичному замечанию В. Дорошевского, "история слов - это история разнообразных контактов Я с не-Я" 15 . История средств выражения противительной семантики одновременно является историей движения и развития идеи противительности.

Современный лексический фонд противительности постоянно пополняется различными способами, например:

1. Образование новых слов по традиционным или единичным, но ставшим продуктивными моделям (например, префикс анти- + все, что угодно в значении признака или предмета: антикризисный, антимидер, Анти-Ахматова и т. Д.; префикс контр- - контр-культура, контр-модерн); расширение сочетаемости этих слов (например, антикризисный + все, что угодно); возникновение окказионализмов - слов, образованных от слов или служебных морфем с противительной семантикой, например: Bопрекист („Литературная газета" 2008, № 52) - от наречия-предлога вопреки; интернет-слово антик ('тот, кто против'), семантически связанное со значением префикса анти-; человек-против („Литературная газета" 2010, № 8) - ср. человек-оркестр, человек-словарь.

${ }^{13}$ Е.Р. С к в а й р с, Русско-ганзейские дипломатические акты как источники для этимологических решений, [в:] Scientific papers of the University of Latvia Linguistics: Studia Etymologica Germano-Balto-Slavica, University of Latvia, Riga 2008, c. 59.

14 В.И. Д а л ь, указ. соч., т. 2, с. 445.

15 В. Д о р о ш е в с к и й, Элементы лексикологии и семиотики, Москва 1973, с. 70. 
2. Расширение поля деятельности слова, в результате чего создается межстилевой „буфер обмена”: например, оппонент или versus - слова, перешедшие из строго очерченного круга книжного употребления в профессиональную (сфера СМИ и рекламы), затем и в общеупотребительную лексику: Нам достался очень сильный оппонент (Sports.ru).

3. Трансформация лексического значения слова и переход его в разряд субъективно-оценочных (ср. прочъ) или актуализация периферийного, стилистически окрашенного значения (разг.: Ну что ты maкая поперечная?).

4. „Разархивация” слова - например в ироничном контексте употребления: Ты что, супротив отияа? (разг.-ироничн.).

5. Активизация традиционных синтаксических моделей, в результате чего возрастает число употреблений слова протия, структурным и семантическим центром которых оно является. Конструкции с проmив формируют мини-текст современного заголовка. Они могут быть субъектно-объектными (Мама против папы), бессубъектными (Против богов) или безобъектными (Народ против).

Если сопоставительный метод оказывается наиболее результативным именно при изучении близкородственных славянских языков 16 , то, разделяя мнение Г.П. Нещименко, думаем, что перспективным направлением могут стать сопоставительные семантические исследования. Применительно к семантике противительности, о которой шла речь выше, можно назвать следующие аспекты: изучение средств выражения семантики и их семантических оттенков в одном языке на фоне других славянских языков, история трансформации значений при формировании противительной семантики и т. д.

16 Г.П. Н е щ и м е н к о, О значимости сопоставительного изучения близкородственных языков, [в:] Слова. Кониепты. Мифы. К 60-летию А.Ф. Журавлева, Москва 2011, c. 252. 